$\begin{array}{ll}\text { Article } & \begin{array}{l}\text { European } \\ \text { Journal } O\end{array} \\ \text { Industrial } \\ \text { Relations }\end{array}$

\title{
Unions in small- and medium- sized enterprises: A family factor perspective
}

European Journal of Industrial Relations 2014, Vol. 20(3) 273-290

(C) The Author(s) 2014

Reprints and permissions: sagepub.co.uk/journalsPermissions.nav DOI: 10.1177/09596801।3519639 ejd.sagepub.com

@SAGE

\author{
Ann-Louise Holten
}

Københavns Universitet, Denmark

\section{Colin Crouch}

University of Warwick, UK

\section{Article by an MPIfG researcher}

Ann-Louise Holten, Colin Crouch: Unions in Small- and Medium-Sized Enterprises: A Family Factor Perspective. In: European Journal of Industrial Relations 20(3), 273-290 (2014). Sage Publications

The original publication is available at the publisher's web site: http://dx.doi.org/10.1177/0959680113519639

\section{Abstract}

Trade unions are commonly weak in small- and medium-sized enterprises, which constitute a majority of European firms and are often family-owned. We investigate the influence of family ownership on employee membership, perceptions and experience with unions in Danish and Italian firms in the textile and clothing sector. Family ownership reduces union membership; and within family firms, the number of family members employed is negatively associated with unionization rates and employee perceptions of unions.

\section{Keywords}

Family firms, hierarchical linear modeling, industrial relations, small- and medium-sized enterprises (SMEs), trade unions

\section{Introduction}

Employment relations in small- and medium-sized enterprises (SMEs) generally compare poorly with larger firms with regard to salaries, fringe benefits, holiday entitlements, training opportunities, working hours and labour turnover (European Foundation, 2001). Employees are also more likely to suffer severe accidents (Champoux and Brun, 2003) and to be exposed to physical and chemical hazards (Eakin et al., 2000). This situation is especially manifest in traditional economic sectors such as agriculture, manufacturing, construction and transport (European Communities, 2002). While trade union

\section{Corresponding author:}

Ann-Louise Holten, Institut for Psykologi, Københavns Universitet, Øster Farimagsgade 2A, København K 1353, Denmark.

Email: ann-louise.holten@psy.ku.dk 
membership and collective agreements are important for combating risks, maintaining good health and safety practices (Eakin et al., 2010; Leka and Cox, 2008) and supporting statutory rights (Brown et al., 2000), the working conditions and lesser degree of formalization of employment contracts in SMEs suggest that their employees may benefit particularly from union presence. However, SMEs often constitute an employment system with a low external regulatory involvement, including union representation.

Many SMEs are family-owned, and in this article we investigate the role of the family factor in determining the degree to which employees are union members, have a positive perception of and experience with unions. We contribute to SME research in the following three ways. First, we compare union membership rates for employees in family and non-family firms. Second, we examine union membership rates, perceptions of and experience with unions for employees who are family member as compared to other employees. Third, we study the role of firm size (by number of employees and number of family members employed) in determining employees' union membership, perception of and experience with unions.

There are various barriers to effective implementation of health and safety initiatives in SMEs: social (informal relations between employees and employer and between colleagues) (De Troyer and Le Lay, 2007), regulatory (limited implementation or absence of control methods) (Gardner et al., 1999), professional (limited health and safety knowledge and competencies) (Antonsson, 1997) and labour organizational (weak unionization and lack of representation) (De Troyer and Le Lay, 2007). In the latter context, SME employees are often reluctant to become union representatives, thus making representation of collective interests difficult (De Troyer and Le Lay, 2007). Arocena and Núñez (2010) find that Spanish SMEs with low unionization and poor employment relations are more likely to adopt no organizational health and safety systems at all. Given that trade union organization helps improve health and safety practices, increasing our understanding of unions in SMEs holds an important potential for increasing health and safety.

Our article makes two proposals for strengthening our understanding of unions in SMEs. The first broadens the traditional operationalization of unionization by introducing a composite measure of employees' action, perception and experience with unions. To this end, we measure three elements: union membership (action); the degree to which employees regard union membership as important (perception); and the degree to which they have personally experienced support from unions (experience). Building on actionspecific perception theory, which explains the reciprocal relationship between action and perception, this composite measure allows a broader understanding of union membership beyond the traditional focus on union density. A union member does not necessarily believe membership to be important or have had positive experiences of union support. We thus propose this composite measure as a stronger representation of union support than the more commonly used density measure. Our composite measure thus simultaneously targets action, perception and experience.

Our second proposal introduces the concept of 'family factor' and its impact on unionism. Though there has been previous research on industrial relations in SMEs (Holliday, 1995; Rainnie, 1989; Ram, 1994; Scott et al., 1990), the direct effect on unionization of family ownership and employment remains unresearched. Our investigation of the 
family factor departs from the classical definition of family firms by family ownership, management and employment. We add to this definition by including the individual employee perspective and relate it directly to the discussion of firm size. We investigate the family factor in three ways: first by comparing family and non-family firms, second by distinguishing between employees who are family members and others and third by studying the number of family members employed as an independent variable.

On this basis, we create a model which aims to test both the interactionistic and the social custom approach to union membership (Schnabel and Wagner, 2007; Visser, 2002). These approaches suggest that union membership is influenced by factors in the social context, such as the living and working environment. We thus investigate the family factor as an example of such social context factors.

Our study covers Denmark and Italy, both countries with a particularly large proportion of SMEs. In 2008, 96.7 percent of all firms in Denmark, and 99.4 percent in Italy, had fewer than 50 employees (European Foundation, 2011). Despite this similarity, Denmark and Italy possess very different industrial relations models, thus introducing variation to the central variable of our study. By including data from these two national systems, we investigate whether there is a common cross-national trend concerning family and unions in SMEs.

\section{SMEs and unions}

The weaker formalization of terms and conditions of employment, higher health and safety risks and less advantageous working conditions in SMEs suggest that SME employees in particular would need and benefit from union membership and collective bargaining coverage. Little precise comparative data are available on the relationship between firm size and industrial relations, though most studies find levels of union membership and collective bargaining coverage to be lower in SMEs than in larger firms (Bouquin et al., 2007; European Foundation, 2001; Kirton and Read, 2007; Marini, 2005; Miller et al., 1996; Wilkinson, 1999).

Kirton and Read (2007) list four major barriers to unionization in SMEs: informal and individualized employment relations, proximity of interpersonal relations (between employer and employees, and between colleagues), employer resistance to the collective articulation of grievances and lack of priority given to SMEs by unions. The importance of these barriers is confirmed by the 2004 Workplace Employment Relations Survey (WERS) in Britain (Forth et al., 2006), which found that small firm managers consult directly with employees (rather than with unions) and are less encouraging towards union membership.

Van Gyes (2006) and Wilkinson (1999) attribute the lower union membership rate in SMEs to employers' adversarial attitude towards unions, making it difficult for unions to organize within small firms. This attitude has been explained by the reluctance to share control and receive criticism (Forth et al., 2006). Moreover, the attitude of employers toward unions is assumed to influences the attitude of employees. Wright (1995) suggests that the most important determinant of union membership is indeed employees' perception of the employer's attitude towards unions. Thus, employers' view of unions may shape employees' union membership, perception and experience. 
Our study involves two industrial relations models, Danish and Italian. The Danish model has three key aspects: a high level of collective organization, high collective bargaining coverage and tripartite social dialogue. Agreements are mostly made directly between employee and employer organizations, involving the state as little as possible. In 2010, trade union density was 67 percent, employer organization density 58 percent and collective bargaining coverage 65 percent (Jørgensen, 2013). Both union density and bargaining coverage have declined in recent years.

Italy has no institutionalized tripartism, yet tripartite agreements have played a central role in the model. The sector is the predominant level for collective bargaining. Trade union density was 36.1 percent in 2011, employer organization density was 58 percent in 2008 and collective bargaining coverage was 80 percent in 2009 (Pedersini, 2013). Trade union density has remained relatively stable in recent years. This also holds true for collective bargaining coverage, which is more than twice as high as the union density. Additionally, subcultural and political differences among regions influence the levels of unionization in SMEs (Trigilia, 1995; Trigilia and Burroni, 2009).

Since SMEs are less detached from the overall national industrial relations systems than in many other countries, both Denmark and Italy are partial exceptions to the general finding of a low role of unions in small firms. The most recent cross-national comparative estimate dates back over a decade (European Foundation, 1999), and found union density as high as 87 percent in Danish firms with ten or fewer employees. No precise statistics were available for Italy, but the level was reported to be 'high' in the regions in which we carried out our research. In neither country was widespread firmlevel collective bargaining reported: in both cases, SMEs depended mainly on sectoral agreements, which had a very high coverage. A more recent attempt to revisit the issue of employment relations in SMEs (European Foundation, 2006) failed to improve on these data, but did report both Denmark and Italy as countries where SME employers were more engaged in employers' associations than in most other countries. The same study found wages in Danish small firms in clothing and textiles to be 91 percent of the level in large firms, while the equivalent level in Italy was only 71 percent. Finally, a statistical study of factors influencing union membership across European economies reported the usual finding that small firm size was associated with lower union density than in large firms, but also that there were exceptions to this in countries with the 'Ghent' system of social insurance, which includes Denmark (Ebbinghaus et al., 2011). Unfortunately, the study did not present country-level data in detail and contained no specific information on Italy. We can conclude from these limited data that, although unions are generally weaker in smaller than in larger firms, they have a sufficient presence in both our countries to make their role worth studying.

\section{SMEs and the family factor}

Family firms are estimated to account for two-thirds of all businesses worldwide (European Foundation, 2002). Within the SME population, in both industrially developed and developing countries, the prevalence of family firms is also high (Matlay, 2002). For example, in Britain the 2004 WERS study found that 78 percent of a SME workplace sample were family-owned and 61 percent of employees were 
owner-managed (Forth et al., 2006). While family firm research has mainly focused on role definition, distribution of power and organizational climate and commitment (Weigel and Ballard-Reisch, 1997), we study the family factor in relation to employees' union membership, perception and experience.

Various criteria have been applied to define family firms and there is a lack of consensus on how they should be classified and studied. Family ownership, family management (Haugh and McKee, 2003; Howorth et al., 2010) and family member employment (Kotey and Folker, 2008) are three classical criteria that alone or in combination have been considered relevant, and we include all three in our definition of the family firm. Most research has approached family firms as a combination of two systems, the business and the family (Pieper and Klein, 2007). By including the employee perspective, we also consider, in accordance with the arguments of Weigel and Ballard-Reisch (1997), the subsystem of the individual.

While family firm employees often comprise both family members and non-members (Feldman, 1984), the family factor is not exclusively related to blood ties but is also reflected in the culture and ethos of the firm (Ram, 2001; Ram and Holliday, 1993). Hence the non-family member employees find themselves working in a complex system, which may have an impact on unionization, employment relations and working conditions. Given the few statistics on non-family member employees in family firms, it is difficult to estimate the extent of this population. However, in a Canadian study, the mean percentage of non-family member employees in family SMEs was estimated at 80 percent (Mitchell et al., 2003). Thus, the population of non-family employees may be of a considerable size.

Danish and Italian family systems are often considered different. Where Danish family systems are described as 'weak' (priority is given to individual values), Italian families are characterized as 'strong' (with a resilience of family loyalty and authority) (Reher, 2005). However, the picture may not be as clear-cut, while strong within-country differences exist (such as the Italian north-south divide). The family systems within these two countries and their potential differences contribute to the variation in our model.

Family-firm employment has been ascribed both positive and negative characteristics. On the positive side are low bureaucracy, quicker and more effective decision-making, fewer impersonal relations, greater flexibility of procedures and action (Kets de Vries, 1993), altruism and loyalty (Pollack, 1985). On the negative side are loosely defined authority and responsibility, blurred decision-making hierarchies, conflict spill-over (Kets de Vries, 1993), confusing and blurred roles for employees (family as well as nonfamily members) (Weigel and Ballard-Reisch, 1997), lack of or inappropriate qualifications (Pollack, 1985) and indulgence. These characteristics correspond to well-known potential predictors of employee health and well-being. Within the job demandsresources model, examples of such predictors are role conflict, support, autonomy, feedback and emotional demands (Bakker and Demerouti, 2007).

\section{Hypotheses}

We develop three hypotheses: H1 focuses on employees in family and non-family SMEs, $\mathrm{H} 2$ on family as against non-family member employees, and $\mathrm{H} 3 \mathrm{a}$ and $\mathrm{H} 3 \mathrm{~b}$ on firm size. 
Different aspects of the family factor may influence the inclination of family firm employees to become union members. One potential influence is the atmosphere and sense of family that such firms generate (Ram, 2001; Ram and Holliday, 1993) and the level of employee identification with the firm (European Foundation, 2001). While being grounded in both family and organizational roles, identification with the firm is at times even emotionally laden (Glynn and Wrobel, 2007). Consequently, by identifying with the firm and being in a family atmosphere, employees may not feel the need for external involvement by unions, as protection and support are provided through the familiar, trusting relationships within the family firm.

Another potential influence is the employers' attitude towards unions (Wright, 1995). Processes of attitude alignment have been observed in close relationships such as marriage and cohabitation (Davis and Rusbult, 2001; Matz and Wood, 2005). We propose that attitude alignment may also occur within the close relationships of small family firms. While small employers in general have a more adversarial attitude towards unions than larger firms (Forth et al., 2006; van Gyes, 2006; Wilkinson, 1999) and their attitude towards unions is a determinant of union membership in employees (Wright, 1995), we hypothesize that union membership rates will be lower in family firms as compared to non-family firms.

H1: Family-firm employees have significantly lower union membership rates than other firm employees.

From the perspective of human identity theory, working as a family member in a family firm simultaneously triggers both main identity-building areas, family and work. These are usually treated as separate and even conflicting entities (Eby et al., 2005), but more recently there have been efforts to investigate positive spillover between identity areas (Wayne et al., 2006). The involvement of more identity-building areas may increase the vulnerability of family member employees, especially in situations of conflict. When identity-building areas are interdependent, a higher degree of readiness to compromise may result (Erikson, 1950). Such compromises may be reflected in an alignment between the values and norms of the individual and the family firm (typically adversarial to union membership). For family member employees, employment relations overlap with family relations. Given this extraordinary overlap between identity areas, we hypothesize that family member employees experience a greater attitude alignment, thus reporting a lower score on our combined Union measure (lower union membership, less positive perceptions and experience).

H2: Family member employees score significantly lower on Union than non-family member employees.

Research has demonstrated a positive relationship between firm size and union membership (Bouquin, 2007; Kirton and Read, 2007; Marini, 2005; Wilkinson, 1999). We extend current research on this relationship by studying SME union membership in an enriched form, using the combined Union measure. We hypothesize that firm size is not only positively related to union membership but also to employees' positive perception of and experience with unions. 
H3a: Firm size (by number of employees) is positively related to employees' score on Union.

Adding to our study of the family factor, we also introduce a firm size concept based on the number of family member employees. Within cognitive dissonance theory it is suggested that group dissonance works as a motivational factor to achieve group consonance (Elliot and Devine, 1994). Therefore, we propose that the more family members are employed in a firm, the higher the behavioural and attitudinal alignment between family and non-family member employees. Hence the greater the family representation, the lower the score on the Union measure.

$H 3 b$ : Firm size (by number of family member employees) is negatively related to employees' score on Union.

\section{Methods and measurements}

\section{Sample}

We applied an information-oriented sampling strategy, selecting countries and industrial areas known for their relatively high union involvement in SMEs. This approach allowed for more variation in our dependent variable than had we included areas with less union involvement. We targeted SMEs in the textile and clothing sector from areas with a high occurrence of small firms: in Denmark, Herning, Brande, Ikast, Kolding and Vejle; in Italy, Prato, Lucca and Pisa.

Data were gathered in 2000-2001, in firms with at least one employee and fewer than 30. Seventy-eight firms participated in the study, 35 in Denmark and 43 in Italy. Data were collected at two levels: individual employee data from questionnaires and employer data from standardized interviews and company records. Questionnaires were distributed to 634 employees and 265 were returned (42\% response rate). In family firms our response rate is considerably lower (34\%) than in non-family firms (57\%). The general response rate of this study lies within the norm recommended by Baruch (1999). For various reasons, research access to small firms is generally difficult (Ram and Holliday, 1993). We attempted to maximize response rates by company visits, agreements on anonymity and continuous contact with owners throughout the data collection phase. As one of the important factors influencing response rates negatively is firm size (Bartholomew and Smith, 2006), the response rate of our study must be considered relatively high. We interviewed 78 owners; all interviews were audio recorded and transcribed.

We selected participating firms to represent a reference population of the industrial districts of Prato and Herning-Ikast, covering the most salient categories in the textile and clothing sector. Within each sector subcategory, we performed a random selection of participants from telephone directories and membership data from employers' organizations. Participating firms were recruited by telephone.

As multi-level analyses require data at all levels, 19 of the initial 78 firms were excluded because of non-response. We thus created a sample for analysis consisting of data from 59 firms (interviews and company records) and 265 employees (questionnaires). Sample characteristics are presented in Table 1. 
Table I. Sample characteristics.

\begin{tabular}{lllll}
\hline & & Family firm & Non-family & Total \\
\hline Denmark & Company interviews & II & 18 & 29 \\
& Employee questionnaires & 72 & 91 & 163 \\
& Mean firm size & 6.5 & 5.1 & 5.6 \\
Italy & Company interviews & 25 & 5 & 30 \\
& Employee questionnaires & 65 & 37 & 102 \\
\multirow{5}{*}{ Total } & Mean firm size & 2.6 & 7.4 & 3.4 \\
& Company interviews & 36 & 23 & 59 \\
& Employee questionnaires & 137 & 128 & 265 \\
& Mean firm size & 3.8 & 5.6 & 4.5 \\
\hline
\end{tabular}

In our sample, 45 percent of the firms are micro-firms (one to nine employees), 61 percent are family firms and 65 percent are members of an employers' organization. Firms in the Danish sub-sample are larger (by number of employees), while there are more family member employees in the Italian sub-sample.

\section{Measurements}

At the individual level, we measured four variables: the dependent variable Union (union membership, perception and experience), the independent variable kinship with employer, and two control variables: wage satisfaction and age.

Union was measured by a new composite scale of three items based on the following questions:

1) Are you a union member (action)?

2) Do you think it is important to be a union member (perception)?

3) Have you ever needed the assistance of a union (experience)?

Response categories were dichotomous (yes/no). The application of dichotomous variables in scale creation has been employed in other research (Agervold, 1998). The scale was tested for internal reliability $(\alpha=0.67)$. To validate the interrelationship between the three items of our composite scale further, we performed a correlation analysis which revealed significant correlations at .01 level between all three items. We also measured simple union membership by item 1 of the above scale.

Kinship with employer was a single item measure. Respondents answered the question: are you related to your employer? Response categories were dichotomous (yes/no).

We chose to control for two individual characteristic determinants of union membership, namely wage satisfaction and age. Wage satisfaction was measured by a single item measure. Respondents indicated the degree to which they were satisfied with their wages. Response possibilities ranged from 'completely satisfied' $(=7)$ to 'completely unsatisfied' $(=1)$. Wage satisfaction was included on theoretical grounds. While our model mainly aims at testing a combination of interactionistic and social custom approaches to 
Table 2. Group statistics and independent samples test.

\begin{tabular}{llllll}
\hline & & $N$ & Mean & SD & SEM \\
\hline Union & Family firm & 136 & 45.59 & 49.99 & 4.29 \\
membership & Non-family & 127 & 58.27 & $49.5 \mathrm{I}$ & 4.39 \\
$t$-test & $F$ & $t$ & d.f. & Mean difference & SED \\
& I.48 & $.23 *$ & 261 & 12.68 & 6.14 \\
\hline
\end{tabular}

Note: $* p<.05$.

union membership, we controlled for a variable strongly related to the frustration-aggression approach, explaining union membership as a result of individuals' frustration (such as dissatisfaction with wages) (Schnabel and Wagner, 2007). Age was self-reported and measured in whole years. This variable was included for statistical reasons as it was correlated with our dependent variable.

At company level, we measured two variables: number of family member employees and number of employees, both extracted from company records. Furthermore, we interviewed owners on their perception of unions and the role unions play in their firms. Firms were categorized as family firms when they were family-owned, family-managed and employed family members.

\section{Statistical analyses}

To prepare data for analysis, response values for all questionnaire measures were transformed into a 0 to 100 scale (100 indicating the highest possible rating of each item). Data analysis was performed in SPSS 17 and HLM 6.02. H1 was tested by $t$-test analysis and supplementary descriptive analyses of interview data. $\mathrm{H} 2$ and $\mathrm{H} 3$ were tested by multilevel analysis.

Data were grand-mean centred at both individual and company level. The issue of centring has been raised by many researchers (Hofmann et al., 2002; Raudenbush and Bryk, 2002; Wu and Wooldridge, 2005). However, the general recommendation is to apply grand-mean-centered modeling as it reduces the collinearity between levels (Wu and Wooldridge, 2005). The applied method of estimation was full maximum likelihood.

\section{Results}

In order to test $\mathrm{H} 1$, we categorized firms as either family or non-family. As seen in Table 2 , employees are more often union members in non-family firms $(M=58.28, \mathrm{SE}=$ 4.39) than in family firms $(M=45.59, \mathrm{SE}=4.29)$. The difference is significant $t(261)$ $=-2.07, p<.05$; effect size $r=.13$. We thus found support for H1. The zero order correlations for all studied variables are seen in Table 3 . In addition, we performed descriptive analyses of interview data on employers' perceptions of unions and the role unions play in their firms. Family-firm owners generally had a more negative perception of unions than non-family firm owners: 85 percent thought unions inhibit flexibility and 
Table 3. Zero order correlations for the multilevel model.

\begin{tabular}{lrrcccccr}
\hline & Mean & SD & I & 2 & 3 & 4 & 5 & 6 \\
\hline I. Age & 36.41 & 11.41 & - & & & & \\
2. Kinship with employer & 12.36 & 32.97 & .04 & - & & & \\
3. Union & 46.43 & 37.81 & $.28^{* *}$ & $-.23^{* *}$ & - & & \\
4. Wage satisfaction & 52.94 & 30.97 & -.01 & $.14^{*}$ & -.11 & - & \\
5. No. of employees & 12.95 & 8.59 & -.01 & $-.25^{* *}$ & $.23^{* *}$ & .03 & - & \\
6. No. of family employees & .94 & 1.21 & .02 & $.18^{* *}$ & $-.31^{* *}$ & -.01 & .00 & - \\
\hline
\end{tabular}

Note: $* p<.05 ; * * p<.01$.

Table 4. Multilevel model test.

\begin{tabular}{|c|c|c|c|c|}
\hline & ICC & Model I (MI) & Model 2 (M2) & Model 3 (M3) \\
\hline & Est. $(t)$ & Est. $(t)$ & Est. $(t)$ & Est. $(t)$ \\
\hline Intercept & -.09 & -.06 & -.11 & -.14 \\
\hline \multicolumn{5}{|l|}{ Individual-level variables } \\
\hline Age & & $.24(3.80)^{* *}$ & $.25(4.09)^{* *}$ & $.19(3.18)^{* *}$ \\
\hline Wage satisfaction & & $-.10(-2.18)^{*}$ & $-.11(-2.36)^{*}$ & $-.11(-2.5)^{*}$ \\
\hline Kinship with employer & & $-.21(-4.59)^{* *}$ & $-.17(-3.47)^{* *}$ & $-.12(-2.36)^{*}$ \\
\hline \multicolumn{5}{|l|}{ Firm-level variables } \\
\hline No. of employees & & & $.02(2.58)^{*}$ & $.01(1.0)$ \\
\hline No. of family employees & & & $-.19(-3.45)^{* *}$ & $-.03(-.52)$ \\
\hline Country & & & & $-.87(-5.26)^{* * *}$ \\
\hline Model test & $\begin{array}{l}\text { Deviance } 2 \\
\text { log-likelihood }\end{array}$ & $\Delta \mathrm{D}$ & $d f$ & $P$ \\
\hline ICC & 691.36 & - & - & - \\
\hline$(M I-I C C)$ & 656.22 & 35.14 & 3 & $.00^{* * * *}$ \\
\hline$(M 2-M I)$ & 646.11 & 10.10 & 2 & $.00 * * *$ \\
\hline$(M 3-M I)$ & 623.00 & 33.22 & 3 & $.00 * * *$ \\
\hline
\end{tabular}

Note: ${ }^{*} p<.05 ; *^{*} p<.01 ; *_{* *}^{*}<.00 \mathrm{I}$; Est: Estimate of regression coefficient; $t$ t $t$-value; $\Delta \mathrm{D}$ : Chi-square; d.f.: degrees of freedom; P: Level of significance.

80 percent that unions intervene too much, as against 42 and 32 percent for non-family firm owners.

The multi-level analyses were performed in five steps: i) ICC Model, ii) Model 1 (individual level), iii) Model 2 (company level), iv) random effect estimation and v) Model 3 (country). For each step, we performed model comparison tests for data fit. Results of the multilevel analyses can be seen in Table 4.

The ICC model gives information on the appropriateness of multilevel analysis as such and an estimation of the degree to which multilevel analysis will add to the explanation of the outcome variation. The ICC for Union is $\rho=.35744 /(.35744+.62387)$, 
which means that $\rho=0.364$. The ICC model thus reveals for the dependent variable Union that 36.4 percent of the variance at individual level is accounted for at company level $(p<.001)$, hence multilevel analyses are appropriate.

Model 1 assumes that the dependent variable is affected by independent variables at individual level. The model is fixed, assuming that the relationship between dependent and independent variables is the same for all individual level units. Moreover, it is assumed that the individual level coefficient is independent of company level variables. The independent variable in the model is: kinship with employer. Age and wage satisfaction were included as control variables to the model. We find a negative association between kinship with employer and Union, that is, non-family member employees report a higher degree of union membership and a more positive perception of and experience with unions than do family member employees. This finding leads us to accept H2. As seen in Table 4, Model 1 is significantly better than the ICC model $(p<.001)$.

In the next step, Model 2 is tested against Model 1. Model 2 assumes that the variance in the dependent variable is also accounted for by company level independent variables. The independent variables included to Model 2 are: number of employees and number of family member employees. We find that the number of employees is positively related to Union, leading to the acceptance of $\mathrm{H} 3 \mathrm{a}$. We also find that the number of family member employees is negatively related to Union, leading to the acceptance of $\mathrm{H} 3 \mathrm{~b}$. Model 2 is significantly better than Model $1(p<.001)$ (see Table 4$)$. We did not identify random effects in Model 2.

As our study is performed in two countries, we tested a Model 3 in which we entered country as control variable. By this change to the model, the company level variables (number of employees and number of family member employees) ceased to be significant. The change in significance is possibly explained by the occurrence of bigger SMEs in the Danish sample and more family member employees in the Italian sample. However, as our aim is not to perform a national comparative study, we did not investigate this model further and accept Model 2 as our final model.

In our final model, we thus find a negative association between kinship with employer and Union. We also find a positive association between Union and number of employees and a negative association between Union and number of family member employees. According to the formula of Snijders and Bosker (1999), our final model explains 24 percent of the variance in our dependent variable, which means that the independent variables in our model contribute significantly to our understanding of SME employees' union membership, perception and experience. However, our results also suggest that other possible explanatory variables are at stake.

\section{Discussion}

\section{The family factor}

In relation to the family factor, we found that non-family firm employees more often report being union members and that non-family member employees report a higher degree of union membership, positive perception and experience. Several perspectives 
within the framework of social custom and attitude alignment theory contribute to our interpretation of these findings.

Family-firm owners in our sample had a more negative perception of unions than other owners. This negative perception may have acted as a downward determinant of union membership among employees. A labour relations climate determined by the owner's negative perception may pose a significant role conflict for employees who are union members (Newton and Shore, 1992). Such potential role conflict may discourage employees from union membership, thereby enforcing social compliance with the norm of non-membership.

While attitudes of friends and family are co-determinants of predispositions towards union membership (Newton and Shore, 1992), among family member employees the (non-)membership and perception of unions may be determined even prior to employment. This is supported in a German context by Goerke and Pannenberg (2004), who find a social custom effect on union density among respondents whose family background was influenced by self-employment. In support of social custom effects on union density, the results of Visser (2002) show a positive influence of both perceived unionization of colleagues and a pro-union climate.

Though our findings on the family factor support the social custom theory, they also suggest refinements. While the social customs surrounding an individual comprise different traditions and practices, a certain hierarchy may exist among these customs, some of which have greater impact and importance than others. For instance, our finding that non-family member employees report a higher degree of Union than family member employees, may suggest that family customs are stronger than peer customs. An additional development to the theory could be offered by testing how different customs interact: by reinforcing or weakening their individual effects.

A satisfaction effect perspective may also contribute to our understanding of the significant difference in union membership, perception and experience between family and non-family member employees. In their US-based study, Beehr et al. (1997) found that family member employees have higher degrees of career satisfaction and organizational commitment and less intention to quit, while non-family member employees report fewer personal advantages in their job. High levels of job satisfaction have been associated with decreased demand for union representation (Farber, 1990), while perceived deprivation and dissatisfaction with employment encourage employees to join unions (Fullagar and Barling, 1989). The satisfaction of family member employees may also explain the lower score on our composite Union measure for this category.

The impact and importance of working in family firms is however not unequivocal. Tagiuri and Davis (1996) describe the attributes of the family firm as inherently ambivalent: the same organizational features account for both strengths and weaknesses. This observation is supported by Holliday (1995), who describes both indulgence and exploitation of family member employees as possible scenarios. We have discussed different perspectives on the relationship between the family factor and unions in SMEs, however, in order to understand the exact process through which owners' perceptions influence family and non-family member employees' union membership, perception and experience, further research is needed. 


\section{Firm size}

It is already well documented that firm size and union membership are positively related. This relationship has been explained by a greater sense of isolation from the employer and inability to influence management in larger firms (DeCotiis and LeLouarn, 1981; Leigh, 1986) and a higher level of organizational loyalty in SMEs (van Gyes, 2006). Our findings confirm and extend these prior findings by introducing our composite Union measure. We find that the larger the firm, the more employees report positive union actions, perceptions and experiences, which suggests that reduced union membership is indeed related to the attitude and experience of employees. Yet, whether and how this is positively aligned, to or negatively imposed by, the employer remains to be fully understood.

We have extended prior studies of firm size by investigating the number of family member employees relative to scores on Union (membership, perception and experience). We find that the simple numerical weight of family member employees is positively associated with a lower Union score. Thus, our study suggests that the family factor affects employees' Union score simply on the basis of how many family members the firm employs. Within the perspective of cognitive dissonance theory, this suggests that the more family member colleagues that non-family employees have, the stronger the potential feeling of cognitive dissonance and motivation to reduce imbalance by low union membership and weak positive perception of and experience with unions.

Despite the small variance in size of the firms in our sample, we find a significant relationship between size and union. This suggests that even within the SME population, size is a factor that affects the actions, attitudes and experiences of employees.

\section{Limitations}

While our study offers new insights, it also has limitations. Research access is an issue in quantitative SME research in general (Matlay, 2002) and also in our study. However, compared to other SME research, we achieved a relatively large number of participating firms. Our use of secondary evidence from a number of countries also strengthens our results and the overall value of our findings. Despite this, we acknowledge the limitations of a small $n$ and therefore view our study as exploratory. Additionally, we selected countries and districts in which union involvement in SMEs is known to be higher than elsewhere. Despite the advantage of studying a phenomenon in a context which allows for greater variance, this methodological choice may also limit the generalizability of our results.

In multi-level analysis, a general rule of thumb for sampling is the 30:30 rule: when including 30 units at company level, each should in its own right contain 30 units at individual level. However, when the research focus is on cross-level interaction or random elements of the analysis, an increase of units at company level and decrease at individual level is feasible (50:20 or 100:10) (Hox, 2002). In SMEs the available informants at individual level are by definition few, as there are few employees in each firm. Thus any SME study will have difficulties in complying with the quantitative individuallevel requirements for multi-level analysis. The average number of units included in the analyses of our study is 59:8: that is, for each company level unit (59) an average of eight 
individual-level units was included. It should be noted that the individual-level units were not evenly distributed.

Notwithstanding the fact that the limited number of countries and firms included urges us to be careful in drawing conclusions, our study does in many ways illustrate that the family factor plays an important role for unions in SMEs. As the population of firms in Europe is composed of a large number of SMEs, and family firms constitute a large proportion thereof, the scope and relevance of the findings of our study are potentially wide.

\section{Future research and concluding remarks}

This study makes a contribution to the understanding of the complex nature of the relationship between family, SMEs and unions. We have shown that the family factor matters, and this should be taken into account in future research. While our model explains approximately one fourth of the variance in SME employees' union membership, perception and experience, it seems relevant to recommend future research to investigate additional explanatory variables. Characteristics which may be important to investigate include family firm history, type of ownership, degree of voluntary involvement by family members and type of kinship. Based on our results, firm size (by number of family member employees) is also revealed as an important variable for future research. The distinction between family and non-family member employees also needs further investigation, as employment conditions may vary considerably for the two categories.

Our findings show that the family factor does play a role in SME employees' membership, perception and experience of unions. This does not necessarily in itself mean that working conditions and health and safety practices in small family firms are poor. However, if and when they are, employees do not have the same tools for combating risks and maintaining health and safety practices at the workplace as other employees. The relative absence of unions in family SMEs may thus be an important obstacle to the upholding of statutory employment rights, improvement and prevention of potentially harmful working conditions.

If union membership, positive perceptions and experiences can contribute to the health and safety in SMEs, how can these elements be increased in small family firms? Based on the theory of attitude alignment between firm owner and employees, one possibility would be to influence the attitude of the owner. As external SME relations are often informal, unions may need new and untraditional approaches to build relations with family firm owners. In conclusion, the family factor has proved important and more research is needed to understand when and how this has negative employee outcomes, and how these can be buffered through employees' union-related actions, perceptions and experiences.

\section{Acknowledgements}

The authors thank the European University Institute for supporting the data collection.

\section{Funding}

This research received no specific grant from any funding agency in the public, commercial, or not-for-profit sectors. 


\section{References}

Agervold M (1998) Spørgeskema til psykosocialt arbejdsmiljø: kortlagning og cendring. Copenhagen: Arbejdsmiljøfondet.

Antonsson A-B (1997) Small companies. In: Brune D, Gerhardsson G, Crockford GW and D'Auria D (eds) The Workplace, vol. 2. Geneva: ILO, pp. 466-477.

Arocena P and Núñez I (2010) An empirical analysis of the effectiveness of occupational health and safety management systems in SMEs. International Small Business Journal 28(4): $398-419$.

Bakker AB and Demerouti E (2007) The job demands-resources model: State of the art. Journal of Managerial Psychology 22(3): 309-328.

Bartholomew S and Smith AD (2006) Improving survey response rates from chief executive officers in small firms: The importance of social networks. Entrepreneurship: Theory and Practice 30(1): 83-96.

Baruch Y (1999) Response rate in academic studies: A comparative analysis. Human Relations 52(4): 421-438.

Beehr TA, Drexler JA and Faulkner SONJ (1997) Working in small family businesses: Empirical comparisons to non-family businesses. Journal of Organizational Behavior 18(3): 297-312.

Bouquin S (2007) Policy recommendations. In: SMALL: Representation and Voice in Small and Medium Sized European Enterprises: Monitoring Actors, Labour Organisations and Legal Frameworks. 5th Framework Program, pp. 3-18.

Bouquin S, Leonardi S and Moore S (2007) Employee representation and voice in small and medium-sized enterprises. An introduction to the SMALL project. In: SMALL: Representation and Voice in Small and Medium Sized European Enterprises: Monitoring Actors, Labour Organisations and Legal Frameworks. 5th Framework Programme, pp. 19-28.

Brown W, Deakin S, Nash D and Oxenbridge S (2000) The employment contract: From collective procedures to individual rights. British Journal of Industrial Relations 38(4): 611-629.

Champoux D and Brun JP (2003) Occupational health and safety management in small size enterprises: An overview of the situation and avenues for intervention and research. Safety Science 41(4): 301-318.

Davis JL and Rusbult CE (2001) Attitude alignment in close relationships. Journal of Personality and Social Psychology 81(1): 65-84.

De Troyer M and Le Lay S (2007) Health and safety in SMEs: The challenge for unions. In: SMALL: Representation and Voice in Small and Medium Sized European Enterprises: Monitoring Actors, Labour Organisations and Legal Frameworks. 5th Framework Programme, pp. 75-85.

DeCotiis TA and LeLouarn JY (1981) A predictive study of voting behavior in a representation election using union instrumentality and work perceptions. Organizational Behavior and Human Performance 27(1): 103-118.

Eakin J, Lamm F and Limborg HJ (2000) International perspective on the promotion of health and safety in small workplace. In: Frick K, Jensen PL, Quinlan M and Wilthagen T (eds) Systematic Occupational Health and Safety Management: Perspectives on an International Development. Amsterdam: Pergamon, pp. 227-247.

Eakin JM, Champoux D and MacEachen E (2010) Health and safety in small workplaces: Refocusing upstream. Canadian Journal of Public Health 101(Suppl. 1): S29-S33.

Ebbinghaus B, Göbel C and Koos S (2011) Social capital, 'Ghent' and workplace contexts matter: Changing union membership in Europe. European Journal of Industrial Relations 17(2): $107-124$ 
Eby LT, Casper WJ, Lockwood A, Bordeaux C and Brinley A (2005) Work and family research in IO/OB: Content analysis and review of the literature (1980-2002). Journal of Vocational Behavior 66(1): 124-197.

Elliot AJ and Devine PG (1994) On the motivational nature of cognitive dissonance: Dissonance as psychological discomfort. Journal of Personality and Social Psychology 67(3): 382-394.

Erikson EH (1950) Childhood and Society. New York: Norton.

European Communities (2002) European Social Statistics. Accidents at Work and Work-related Health Problems. Luxembourg: Office for Official Publications.

European Foundation (1999) Industrial Relations in SMEs. Dublin: European Foundation.

European Foundation (2001) Employment Relations in Micro and Small Enterprises in the EU: Literature Review. Dublin: European Foundation.

European Foundation (2002) Family Businesses: Do they perform better? Literature Review by London Economics. Dublin: European Foundation.

European Foundation (2006) Employment Relations in SMEs. Dublin: European Foundation.

European Foundation (2011) SMEs in the Crisis: Employment, Industrial Relations and Local Partnership. Dublin: European Foundation.

Farber H (1990) The decline of unionization in the United States: What can be learned from recent experience? Journal of Law and Economics 8(1): S75-S105.

Feldman DC (1984) The development and enforcement of group norms. Academy of Management Review 9(1): 47-53.

Forth J, Bewley H and Bryson A (2006) Small and Medium-sized Enterprises: Findings from the 2004 Workplace Employment Relations Survey. London: ESRC, ACAS and PSI.

Fullagar C and Barling J (1989) A longitudinal test of a model of the antecedents and consequences of union loyalty. Journal of Applied Psychology 74(2): 213-227.

Gardner DG, Carlopio J, Fonteyn PN and Cross JA (1999) Mechanical equipment injuries in small manufacturing businesses. Knowledge, behavioural, and management issues. International Journal of Occupational Safety and Ergonomics 5(1): 59-71.

Glynn MA and Wrobel K (2007) My family, my firm: How familial relationships function as endogenous organizational resources. In: Dutton JE and Ragins BR (eds) Exploring Positive Relationships at Work. Building a Theoretical and Research Foundation. Mahwah, NJ: Lawrence Erlbaum Associates, pp. 307-323.

Goerke L and Pannenberg M (2004) Norm-based trade union membership: Evidence for Germany. German Economic Review 5(4): 481-504.

Haugh HM and McKee L (2003) 'It's just like a family': Shared values in the family firm. Community, Work and Family 6(2): 141-158.

Hofmann DA, Morgeson FP and Gerras SJ (2002) Climate as a moderator of the relationship between leader-member exchange and content specific citizenship: Safety climate as an exemplar. Journal of Applied Psychology 88(1): 170-178.

Holliday R (1995) Investigating Small Firms: Nice Work? London: Routledge.

Howorth C, Rose M, Hamilton E and Westhead P (2010) Family firm diversity and development: An introduction. International Small Business Journal 28(5): 437-451.

Hox J (2002) Multilevel Analysis. Techniques and Applications. Mahwah, NJ: Lawrence Erlbaum Associates.

Jørgensen C (2013) Denmark: Industrial relations profile. Available at: www.eurofound.europa. eu/eiro/country/denmark.pdf

Kets de and Vries MFR (1993) The dynamics of family controlled firms: The good news and the bad news. Organizational Dynamics 21: 59-71.

Kirton G and Read I (2007) Inequalities in Europe's SMEs: The challenges for a trade union agenda. SMALL: Representation and Voice in Small and Medium Sized European Enterprises: 
Monitoring Actors, Labour Organisations and Legal Frameworks. 5th Framework Programme, pp. 100-110.

Kotey B and Folker C (2008) Employee training in SMEs: Effect of size and firm type, family and non-family. Journal of Small Business Management 45(2): 214-238.

Leigh DE (1986) Union preferences, job satisfaction, and the union-voice hypothesis. Industrial Relations 25(1): 65-71.

Leka S and Cox T (2008) PRIMA-EF. Guidance on the European Framework for Psychosocial Risk Management. A Resource for Employers and Worker Representatives. Nottingham: I-WHO Publications.

Marini D (2005) L'Italia delle Imprese. Treviso: Fondazione Nord Est.

Matlay H (2002) Training and HRD strategies in family and non-family owned small businesses: A comparative approach. Education and Training 44(8/9): 357-369.

Matz DC and Wood W (2005) Cognitive dissonance in groups: The consequences of disagreement. Journal of Personality and Social Psychology 88(1): 22-37.

Miller P, Miller P and Mulvey CHAR (1996) Unions, firm size and wages. Economic Record 72(217): 138-151.

Mitchell RK, Morse EA and Sharma P (2003) The transacting cognitions of nonfamily employees in the family businesses setting. Journal of Business Venturing 18: 533-551.

Newton LA and Shore LM (1992) A model of union membership: Instrumentality, commitment, and opposition. Academy of Management Review 17: 275-298.

Pedersini R (2013) Italy: Industrial relations profile. Available at: www.eurofound.europa.eu/ eiro/country/italy.pdf

Pieper TM and Klein SB (2007) The bullseye: A systems approach to modeling family firms. Family Business Review XX(4): 301-319.

Pollack RA (1985) A transaction cost approach to families and households. Journal of Economic Literature 23: 581-608.

Rainnie A (1989) Industrial Relations in Small Firms: Small isn't Beautiful. London: Routledge.

Ram M (1994) Managing to Survive. Working Lives in Small Firms. Oxford: Blackwell.

Ram M (2001) Family dynamics in a small consultancy firm: A case study. Human Relations 54(5): 395-418.

Ram M and Holliday R (1993) Relative merits: Family culture and kinship in small firms. Sociology 27: 629-648.

Raudenbush SW and Bryk AS (2002) Hierarchical Linear Models, 2nd edn. London: SAGE.

Reher DS (2005) Family ties in western Europe. In: Dalla Zuanna G and Micheli GA (eds) Strong Family and Low Fertility: A Paradox? New Perspectives in Interpreting Contemporary Family and Reproductive Behavior. European Association for Population Studies. Springer Science \& Business Media Inc.

Schnabel C and Wagner J (2007) Union density and determinants of union membership in 18 EU countries: Evidence from micro data, 2002/03. Industrial Relations Journal 38(1): $5-32$.

Scott M, Roberts I, Holyrod G and Sawbridge D (1990) Management and Industrial Relations in Small Firms. London: Department of Employment.

Snijders TAB and Bosker RJ (1999) An Introduction to Basic and Advanced Multilevel Modeling. London: SAGE.

Tagiuri R and Davis J (1996) Bivalent attributes of the family firm. Family Business Review 9(2): 199-208.

Trigilia C (1995) A tale of two districts: Work and politics in the Third Italy. In: Bagnasco A and Sabel CF (eds) Small and Medium-Size Enterprises. London: Pinter, pp. 31-50. 
Trigilia C and Burroni L (2009) Italy: Rise, decline and restructuring of a regionalized capitalism. Economy and Society 38(4): 630-653.

van Gyes G (2006) Industrial Relations in Europe. Luxembourg: European Commission.

Visser J (2002) Why fewer workers join unions in Europe: A social custom explanation of membership trends. British Journal of Industrial Relations 40(3): 403-430.

Wayne JH, Randel AE and Stevens J (2006) The role of identity and work family support in work family enrichment and its work-related consequences. Journal of Vocational Behavior 69(3): 445-461.

Weigel DJ and Ballard-Reisch DS (1997) Merging family and firm: An integrated systems approach to process and change. Journal of Family and Economic Issues 18(1): 7-31.

Wilkinson A (1999) Employment relations in SMEs. Employee Relations 21(3): 285-295.

Wright P (1995) Union membership and coverage: A study using the nested multinomial logit model. International Journal of Manpower 16(2): 53-59.

Wu Y-WB and Wooldridge PJ (2005) The impact of centering first-level predictors on individual and contextual effects in multilevel data analysis. Nursing Research 54(3): 212-216.

\section{Author biographies}

Ann-Louise Holten is Postdoctoral Researcher at the Department of Psychology, University of Copenhagen.

Colin Crouch is Emeritus Professor at the International Centre for Governance and Public Management, Warwick Business School, University of Warwick. 